\title{
Board Of Directors' Diversity And Effect On Strategy. A Study Of The Lebanese Banking Industry
}

\author{
Jacques L. Hendieh
}

Faculty of Business Studies, Arab Open University, Lebanon

doi: 10.19044/esj.2016.v12n13p257 URL:http://dx.doi.org/10.19044/esj.2016.v12n13p257

\begin{abstract}
The purpose of this study was to examine the effect of the functional background diversity of boards of directors on banks' strategy. This relationship is examined using the annual reports between 2005 and 2014 for 16 Lebanese banks. Logistic regression analysis indicates that board diversity is positively associated with the strategies adopted by banks. Implications for both strategic management and future research are discussed.
\end{abstract}

Keywords: Functional background, Board of directors, Strategy, Crisis, Banks

\section{Introduction}

With the recent financial crisis that hit the world, the importance and weight of the banking sector are highlighted. Many researchers have tried to analyze the crises and their effects. The Basel Committee has issued several reports (Basel I, Basel II and Basel III), to try to govern banks and protect stakeholders.

The financial instability and the recent crisis marked the global economy, especially the emerging and developing ones that were affected by very large bank failures, which is not the case in Lebanon. Lebanon has experienced major economic and financial crises since 2006. What is interesting is that the banking sector is still experiencing some stability despite these internal and regional crises.

The strategic choice is still considered a theoretical and managerial challenge. Academics and practitioners have studied this process from various angles. Both of them agreed on the complexity and multiplicity of factors that may affect the strategic choice. There are several empirical studies, especially in the United States, which focus on this subject.

The majority of the existing literature on banking crises seeks especially to analyze its causes. There is a lack of studies that focused on 
analyzing the effect of the functional origin of the management teams (Top Management Teams and Board of directors) on strategic choices in times of crisis. This prompted us to analyze the possible link between the functional origin of the Board of Directors and the strategies adopted by Lebanese banks in times of crisis.

The first concept identified in this research would be to study the effect of functional origins of directors on the chosen strategies. The second identified concept in this research would be to study the effect of crisis sis on the strategies adopted by the banks.

To examine the relationship between board of director diversity and banks strategies, we first discuss the Lebanese banking sector. Then we discuss the concepts of strategy, the Functional background, the relationship between Diversity and strategy and the crisis in banks. Finally, we examine the specific relationship between board diversity and banks strategies.

\section{The Lebanese banking sector}

Lebanese banks play an important role in financing the Lebanese economy and a critical role in stabilizing monetary policy and in the development of the payment systems. In addition, This banking sector is by far the most advanced sector in Lebanon with total deposits of about 60 billion US dollars, which is equivalent to more than three times its gross domestic product (GDP) (Shahin and Safieddine, 2008).

Some studies on the banking sector have found that it is the complexity of the financial systems in place that led to bad practices (Albouy, 2013). Others tried to analyze the specifics of bank governance which functions to limit excessive risk taking (Scialom, 2013; Lopez, 2010).

There are two regulating bodies in Lebanon. Banks and other financial institutions are all under the jurisdiction of the central bank, the Bank of Lebanon (BDL), which holds the authority of regulating the industry. The central bank controls the entry of banks in the industry, defines the fields of banking and creates prudential banking regulations and codes of practice. The Banking Control Commission (BCC) established in 1967 holds supervisory authority over the banking sector. It is responsible for supervising banking activities and ensure compliance with the various banking and financial regulations. The banking activities are also subject to the Code of Commerce (1942) and the Code of Money and Credit (1963).The recent progress, especially in the last decade, wouldn't be possible without the presence of a suitable banking regulation, supervision made by the BDL and the BCC, and cooperation with the Association of Lebanese Banks (ABL) (BDL, 2016).

The banks have become the weak link in the international financial systems while in Lebanon, they remain key players, and the Lebanese 
banking sector has remained stable and financially strong. Banks continue to have a vital role in the economy, in which banks continue to dominate the financial system and remain the main lenders for individuals and companies. Several annual studies showed that this sector remains the main driver of growth in Lebanon (IMF, 2009; World Bank, 2011; ABL, 2016).

The position of Lebanese banks is unique in the Middle East with a rapid development since the 1990s. During the 2007 financial crisis, Lebanese banks have remained secure and totally unaffected by the crisis, because of the legislation of the "Lebanese Reserve Banks "that does not allow Lebanese banks to invest in structured products at high risk. Moreover, Lebanese banks have always maintained a relatively high liquidity in Lebanese pounds (LBP) and foreign currencies spread between domestic and external markets. The liquidity in this sector has played an important role in safeguarding the banking sector (Zreika and Elkanj, 2011).

Deposits, profits and lending activities have been increasing since 2003. The Financial crisis have given Lebanese banks a huge boost with an increase in deposits of $15.6 \%$, total assets of $14.6 \%$, total loans of $18.64 \%$ and net profit by nearly $30 \%$ in 2008 . Most banks in advanced economies depend on credit or financial markets as the main sources of funding while Lebanese banks depend on deposits.

The Lebanese banking sector has experienced a healthy activity period after the financial crisis of 2007, with an unprecedented growth in lending. In total, loans increased by 58.35\%: 15.32 billion US dollars in 2006 to 24,259,000,000 in 2009. This means that banks have been able to provide the credits needed to grow the economy while other credit banks around the world have witnessed subdued lending activities in the context of a slow recovery (Zreika and Elkanj, 2011).

In conclusion, the Lebanese banking sector was and still financially stable. It plays an important role in the Lebanese economy, in which banks dominate the financial system of the country and are the major suppliers of credits to individuals and enterprises.

\section{Strategy}

The strategies are organized according to factors around the company and are in some way related to the behavior of the organization. A vast literature exists on the role of individuals, such as the CEO, in the development of strategies, the results of the strategic behavior studies were generally:

- $\quad$ Focused on the strategic choice (e.g. types of diversification);

- $\quad$ Focused on the outcomes (measured for example by using some indicators of success such as profits or revenues ...). 
Some banks have had striking success (Bank One in the late 90s), while others lived spectacular failures simultaneously (Dresdner Bank and Deutsche Bank in Germany, after their failed a merger attempt in 2000). Is it a bad strategic choice?

The changes that happened in the banking industry around the world over the last 15 years are a good indicator. These failures are often attributed to poor definition of strategy or an error in the pursuit of goals.

Banks have recognized the need to redefine and to improve their strategic formulating in order to avoid failure. In recent years, the strategic transformations of several major international banks were numerous and unexpected, especially during crises, but there is no exact recommendation on strategic options for these banks. These strategies are part of a field whose perimeter is clear and defined: to set limitations over the activities and to avoid dispersion. Among the variables affecting the strategies of a bank, we found the types of products or services, the customers, the technology available and the geographic area in which banks operate.

In 1996, Porter defined competitive strategy as "About being different. It means deliberately choosing a different set of activities to deliver a unique mix of value". Strategy is "The art of building sustainably profitable advantages over their environment by reducing uncertainty, innovation, locks, synergies, flexibility”. Diemer (2010) classified diversification strategies by reasoning in terms of objectives pursued or material contexts in which companies are located. He classified these strategies into two types: defensive diversification which is motivated by the need to supplement or replace a defective core business and the offensive diversification which is adopted in order to take advantage of an existing competitive advantage and to master new technologies.

The Lebanese banks had an expansion in their activities during the latest economic crisis. The Lebanese banking sector has remained stable, which led the Lebanese banks to choose diversification strategies (BDL, 2016). In our research we found the strategic choices could be classified under two categories

- Defensive strategy;

- Offensive strategy.

\section{Functional background}

The skills and cognitive bases of a person is largely a reflection of his / her level of education. A more educated person will have a wider and more complex cognitive functioning (Dollinger, 1984).

The functional origin of the Boards of Directors has been studied since the early 1980. Gupta in 1984 found that in regards the directors of non-diversified companies, the functional origin in accounting or in finance 
is more important than experience in any other field. While in regards of the directors of a vertically integrated companies, a functional origin in production or in operations may be the most critical. In the case of diversified companies with shared resources and common facilities, the functional background in marketing and sales, production and research and development is the most important. This means that the intention of gaining market share appears to have particularly strong demand for marketing skills.

In 1993, Fligstein found that people "who have spent their careers in the marketing of production are mainly interested in increasing product sales ... Having spent their careers in the analysis of problems from a certain theoretical point of view, they will see and analyze all problems through this specific theoretical perspective." The Data that he used from US companies for the period 1919 - 1979 showed that the origins of CEOs are linked to their organization and to the strategies adopted.

Other found contradictory results, the directors in highly diversified companies - having strategies that are related or unrelated - generally have little knowledge of the business operation, the industry, the technology, the geographic region (Dundas and Richardson, 1982). These directors tend to focus almost exclusively on the financial results, including the profit for the period and the rate of return on investment (Hoskisson et al., 2000; Hoskisson et al, 1999).

Several studies have shown that leaders are chosen because they bring a needed experience or because they adapt to the applied diversification strategies. (Awino et al, 2011; Tihanyi et al, 2000; Finkelstein and Hambrick, 1996;; Michel and Harnbrick, 1992; Bantel and Jackson, 1989; Song, 1982). In the literature there is a vast number of studies that investigated the relationship between strategies and the functional origins of CEOs and boards of directors. Most of these studies agree on the fact that the functional origin in terms of education or experience is connected to the strategic choice of the company. This fact has motivated us to go further in exploring this link.

\section{Diversity and strategy}

Lado et al. (1992) argued that the managerial characteristics are considered one of the most important skills that benefit businesses in the formulation of the strategy.

Traditionally, the board was seen as powerless and even useless, but this vision has changed and directors are seen as an active part in the companies, just as the CEOs. Both directors and CEOs should work together to improve the management of the company and to choose better strategies. Salem and Hamza (2003) found that the behavior of the directors has undergone two major changes: first from passive into active, second from the 
de-contextualized into the contextualized roles. Directors today have become an active and socialized part of the firm.

Figure 1: Model depicting the relationship between board compositions of the corporate

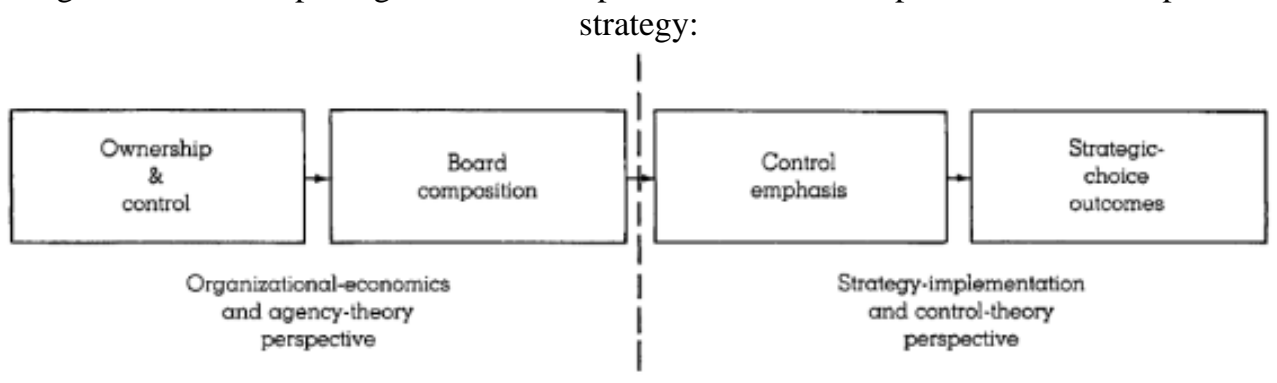

Source: Hoskisson and Baysinger, (1990)

Hoskisson and Baysinger (1990) describe the relationship between the board composition and strategy. Directors must intervene based on the financial performance of the company, or according to their direct observations of the decision making process. However, the ability to perform this function is not the same in all types of companies, especially when the quantity and quality of information held by internal directors is higher than those held by outside directors. Previously in 1989, the same authors found evidence that the choice of strategies is affected by the way internal controls are structured between directors and CEOs. A well-organized work in a company involves parties that are responsible for the formulation and implementation of strategies, and other parties that provide capital and are willing to assume the risk of loss (Jensen and Meckling, 1976). The support of risk is needed when strategic assets are deployed, because it is not known if the difference between the revenues and the costs of production and distribution will be positive, negative or zero. For this reason, it is best to assign responsibility of control the board, avoiding that CEOs being the only evaluators of their own performance and therefore offers a certain guarantee for the investments.

Hendry and Kiel (2004) argued that the boards are held accountable to the organizations they lead. They recommended that administrators, because of their experience and the fact that a thorough understanding of the strategy of a company facilitates the control function, should work with the CEOs in the development of strategic plans.

Hilb in 2005 in his study on the boards, found four main conditions for the successful development, implementation and monitoring of the company's strategy:

- $\quad$ The composition of strategic board;

- $\quad$ Constructive culture and the openness of the Board;

- $\quad$ Effective board structure; 
- $\quad$ And the orientation of the board as a measure of success.

The theories and research on social learning processes suggests that boards are more favorable to consider adopting the strategies of other organizations when these strategies are associated with favorable outcomes (Haunschild and Miner, 1997).

Some found that the functional origin of the CEO will have a small effect compared to the effect of the board Westphal and Frederickson (2001). In a recent study, the Central Bank of Lebanon found that the majority of Lebanese banks chose diversification as a growth mode (BDL, 2016).

We draw from these studies that the characteristics of the directors will have an effect on the selection, implementation, and control of strategies. In our article, we try to prove that the functional origins of the board will influence the strategic choices especially in times of crisis.

\section{Other factors linked to strategies}

In the literature we found many factures related to strategies. One of the most important variables studied is the age of the directors, older directors tend to be more cautious (Hambrick and Mason, 1984).

Some studies have shown that moderate levels of demographic homogeneity or similarity of behavior help to promote integration between board members, while a great diversity is a source of conflict and an element that will limit the productivity of the group (O'Reilly, Snyder and Boothe, 1993).

Sanders and Carpenter (1998) suggest that the size of the board reflects the diversity of its members, their backgrounds, their sources of information, especially their collective ability to handle complex information arising from globalization. However, the size of the team is usually alone a poor indicator of the diversity (Finkelstein and Hambrick, 1996).

\section{Crisis in Banks}

The failure of a large bank or of several banks in one country can cause sudden contraction of the money supply or the bankruptcy of the payment system. This can result in a serious disorder of the economy that creates obligations for the government. The bankruptcy of a bank, even the smallest, can lead to a loss of confidence in the system, even if the government in question is capable of handling the banking crisis in a systematic and orderly manner (www.fao.org).

Despite all efforts to support financial stability, the banking industry in many "developed" and "developing" countries has experienced several difficulties since the 80's. The affected financial institutions have suffered severe losses; some of them became insolvent, while others went bankrupt. In addition, in many developing countries, banking crises were very 
frequent. A large proportion of insolvencies in the banking systems were partially caused by macro-economic events (The World Bank, 2011).

In developing countries in general and Lebanon in particular, it is difficult to gather reliable information about the financial crisis. Although many causes of financial crises in developing countries are similar to those observed in industrialized countries, the situation is more complex. Problems can be macro-economic, sectorial and institutional.

The majority of these problems that are related to the economic policies were linked to common deficiencies. Among the most common causes (Angora and Tarazi, 2011):

- $\quad$ Banks were poorly managed;

- $\quad$ Evaluations of loans and monitoring were insufficient;

- $\quad$ Loans to customers recognized in difficulty;

- $\quad$ Banks owned unbalanced portfolios;

- $\quad$ Lack of internal control;

- $\quad$ High operational costs;

- $\quad$ Inadequate policies adopted by banks facing difficulties;

- $\quad$ Bankers pledged to suspicious transactions, especially in the real estate sector, in order to acquire funds to cover losses during crises;

- $\quad$ Existing fraud to cover certain cases of bank failures.

In developing countries, the instability of financial institutions should've been controlled by the financial regulation and by the banking supervision authority, which is the case in Lebanon. But the banking supervision authority was often subject to political pressure from powerful interest groups who control the banking and commercial sectors. Throughout Latin America, Asia and Africa, bank supervision was unable to maintain control on banks in difficulties, which aggravated the effects of crisis (Polizatto, 1990).

In 2008, a global financial crisis occurred. This financial crisis had started earlier in 2007 with the loss of confidence in the real estate markets in the United States. Because of this credit crisis in the US, there was a global reduction of all expenses, greatly affecting the global economy. This created a period of high volatility, followed by the failure of many banks around the world. Many large multinational financial institutions have experienced an imminent failure.

The main causes of these crises were (Boyer et al., 2004; Stiglitz and Uy; 1996):

- macroeconomic instability related to inadequate economic and financial policies;

- $\quad$ Bad bank management;

- $\quad$ Fraud;

- $\quad$ Cascade bankruptcy from foreign banks. 
Crises and uncertainty cause instability. The stability of the financial and banking system is a major economic concern of any government especially in developing countries where the economy depends on this system.

\section{Hypothesis}

The purpose of our study is to find a relationship between the selected variables in the Lebanese banking sector. We have chosen to limit the empirical part of our research on four assumptions that we believe important to the commercial banking sector in Lebanon. Several reasons justify our choice of the key factors among a large number that exists in the literature.

Research in the banking sector and in other sectors has shown the important role played by these factors. In addition, the qualitative studies of one or more banks also demonstrated the importance of these factors. The interviews with board members guided us to these factors. Previous research showed that the skills and cognitive bases of a person is largely a reflection of their level of education. Several studies examining the effects of the characteristics of boards (such as size, age, demographics, heterogeneity, functional origin, etc.) on the process of strategic decision (Carson et al, 2004). All these studies validate several theories of decision making within groups. They can provide a theoretical basis for understanding the effects of board characteristics on strategic decision making process (Hambrick et al., 2005, Daellenbach et al., 1999; Hambrick and Mason, 1984).

Watson et al. (1993) showed that in a homogeneous team, members tend to act, to think and to behave in very similar ways. It would be important to know whether these groups adopt a defensive strategy in times of crisis.

Our first set of hypotheses is:

H1a: In normal times, a homogeneous Board chooses an offensive strategy of diversification and growth.

H1b: In times of crisis, a homogeneous Board chooses a defensive strategy.

The heterogeneity is often seen as one reason for productivity and innovation in teams, groups and organizations (Bantel and Jackson, 1989; Mannix and Neale, 2005). The increase in heterogeneity improves the quality of ideas and promotes creativity, especially in complex crisis environments (Milliken and Martins, 1996; Boeker, 1997; Van Knippenberg et al, 2004; Cannella et al., 2008; Deszo and Ross, 2012). These studies showed that the teams with different functional backgrounds have advantages regarding the strategic choice (e.g., Hambrick et al., 1996) because they engage in a more comprehensive research using more information from multiple sources 
(Hastie and Tibshirani, 1986). These heterogeneous teams consider several solutions and have more creativity in their actions (Bantel and Jackson, 1989; Eisenhardt and Schoonhoven, 1990; Wiersema and Bantel, 1992).

Our main concern is to test whether a heterogeneous group can be structured to pull the benefits of heterogeneity, even in times of crisis.

Our second set of hypotheses is:

H2a: In normal times, a heterogeneous Board chooses an offensive strategy of diversification and growth.

H2b: In times of crisis, a heterogeneous Board chooses an offensive strategy of diversification and growth.

\section{Method}

\section{Sample}

This study is based on a sample of 16 Lebanese banks operating in Lebanon. It covers a period of ten years, between 2005 and 2014. The composition of this sample is random. The size of the selected management teams varies between 4 and 13 members, with an average of 9 members.

Data on education of board members, the size of the bank, the number of members, the experience of members and the average age of members was collected by various means: from the annual reports; from the personal pages of some members, or from face-to-face or telephone interviews with the board members. All the previous variables were measured using nominal scales.

\section{Measures}

1. The composition of Boards

Many studies used the functional origin as the independent variable (Buyl et al, 2010; Cao et al., 2010; Canella et al., 2008; Boone and Hendriks, 2007; Herrmann et Datta 2005; Menguc and Auh, 2005; Carpenter, 2002; Finkelstein and Hambrick, 1996; Hambrick et al, 1996). Similar to these studies, we chose to test/divide this functional origin into two groups, homogeneous and heterogeneous.

To measure the composition of boards, we used the educational background of members. We divided the boards, into two groups:

- If more than $50 \%$ of members have similar education, the team is considered homogeneous.

- If less than $50 \%$ of members have a similar education, the team is considered heterogeneous.

We measure the experience in terms of years spent by the member in the banking industry.

2. Strategy 
We have chosen to use the paragraph approach "Paragraph Approach" of Miles and Snow (1978). This approach has already been used in studies in the banking sector. For example, James and Hatten (1995) investigated the validity of this paragraph approach in the banking industry using the typology of Miles and Snow, and concluded that this measuring instrument is useful and valid. In a recent study, O'Regan and Ghobadian (2006) proved that this paragraph approach is an appropriate and reliable medium to classify the strategies of companies.

While we were coding the speeches of leaders, we found that two types of strategies exist: offensive strategies of diversification and defensive strategies of diversification. So we opted to test strategies in offensive and defensive (Plambeck and Weber, 2010). We were also influenced by the study Hambrick et al. (1996), which tested the effect of the heterogeneity of Top management teams on business performance by coding the strategies into offensive and defensive. Diemer (2010) found two types of strategies: "It may well be a defensive diversification driven by the need to supplement or replace a faulty core business, or an offensive diversification intended to enjoy a competitive advantage and master new technologies."

\section{Crisis}

To better understand the effect of the crisis, we used a binary measure, where 0 is for normal periods without crisis, and 1 for the crisis periods (Chevet, 1993). These data were collected on the Central Bank's website and from the Association of Lebanese Banks.

\section{Control variables}

Most of the previous studies (Hambrick and Mason, 1984; Carpenter, 2002; Herrmann and Datta, 2005; Hambrick, 2007; Cannelle et al., 2008; Cao et al., 2010) used similar control variables in terms of age, company size and the size of the teams. In coding the boards' size we used the number of members, as for the age we used the average age of the members. The size of the bank and the size of the board were collected from the annual reports and used in log.

\section{Analysis}

In this article we have chosen to use logistic regression to test our hypotheses for a basic reason, that is that Logistic regression analysis requires that the dependent variable is dichotomous and the independent variables could be metric or dichotomous.

Our model consists of six variables, four control variables, a moderating variable and the dependent variable as the pillars of our implementation research scheme. 


\section{Results}

Overall, two regressions were performed. The binary logistic regression is conducted twice, once for the homogeneous group and once for the heterogeneous group.

Then moderation tests were performed to examine whether the control variables such as age, bank size and group size will affect the relationship between the independent variable and the dependent variables.

Results obtained for the homogeneous group

Table 1: Tests of model specification:

\begin{tabular}{|l|c|c|c|c|}
\hline \multicolumn{2}{|c|}{} & chi-square test & ddl & Sig. \\
\hline \multirow{3}{*}{ Step 1 } & Step & 7.125 & 1 & .004 \\
\cline { 2 - 5 } & Bloc & 7.125 & 1 & .004 \\
\cline { 2 - 5 } & Model & 29.476 & 4 & .000 \\
\hline
\end{tabular}

In a hierarchical logistic regression, the presence of a relationship between the dependent variable and combination of independent variables entered after the control variables have been included is based on the statistical significance of the block chi-square for the second block of variables in which the predictor independent variables are included.

In this analysis, the probability of the block chi-square (7.125) was 0.004 less than or equal to the level of significance of 0.05 . The null hypothesis that there is no difference between the model with only a constant and the control variables versus the model with the predictor independent variables was rejected. The contribution of the relationship between the predictor independent variables and the dependent variable was supported.

Table 2: Variables in the equation

\begin{tabular}{|c|c|c|c|c|c|c|c|}
\hline \multicolumn{2}{|c|}{} & B & E.S. & Wald & ddl & Sig. & Exp(B) \\
\hline Step $1^{\mathrm{a}}$ & Experience & -.091 & .121 & .563 & 1 & .453 & .913 \\
\cline { 2 - 8 } & Age & -.063 & .101 & .591 & 1 & .296 & .937 \\
\cline { 2 - 8 } & Size_Bank & .000 & .000 & 2.372 & 1 & .101 & 1.000 \\
\cline { 2 - 8 } & Crisis & 1.601 & .565 & 6.127 & 1 & .007 & 6.35 \\
\cline { 2 - 8 } & Constant & 6.780 & 6.014 & 1.997 & 1 & .122 & 2234.098 \\
\hline
\end{tabular}

a. Variable(s) entered in step 1: Crisis.

We noticed that none of the independent variables in this analysis had a standard error larger than 2.0. The check for standard errors larger than 2.0 does not include the standard error for the Constant.

The probability of the Wald statistic for the variable "Crisis" is 0.007 $<0.05$. The null hypothesis that the $b$ coefficient for Crisis was equal to zero was rejected. This means crisis coefficient is significantly different than 0 . This supports the relationship that "in times of crisis" homogenous teams are 
more likely to choose defensive strategies, approximately 6 times more likely to choose defensive strategy. And in normal times they are less likely to choose defensive strategies, so more likely to choose offensive strategies. The value of $\operatorname{Exp}(\mathrm{B})$ was 6.35 ( $>1$ and $\mathrm{B}>0$ ) which implies that if one unit increases in "Crisis" it increases the odds by approximately six times that board members choose defensive strategies.

The crisis factor influences the strategy chosen by homogeneous boards. The results confirm both hypotheses H1a and H1b.

Results obtained for the heterogeneous group

Table 3: Tests of model specification:

\begin{tabular}{|l|l|l|l|l|}
\hline \multicolumn{2}{|l|}{} & chi-square test & ddl & Sig. \\
\hline \multirow{3}{*}{ Step 2 } & step & .000 & 1 & 1.000 \\
\cline { 2 - 5 } & Bloc & .000 & 1 & 1.000 \\
\cline { 2 - 5 } & Model & 31.127 & 4 & .000 \\
\hline
\end{tabular}

In this test, the probability of the block chi-square was 1 greater than the level of significance of 0.05 . We cannot reject the null hypothesis that there is no difference between the model with only a constant and the control variables versus the model with the predictor independent variables. The contribution of the relationship between the predictor independent variables and the dependent variable was not supported. There is no relationship between the crisis and the strategies for the heterogeneous boards.

Table 4: Variables in the equation

\begin{tabular}{|c|c|c|c|c|c|c|c|}
\hline \multicolumn{2}{|c|}{} & A & E.S. & Wald & ddl & Sig. & $\operatorname{Exp(B)}$ \\
\hline \multirow{3}{*}{$1^{\mathrm{a}}$} & Experience & -2.353 & 2669.828 & .000 & 1 & .988 & .105 \\
\cline { 2 - 8 } & Age & -6.460 & 2894.717 & .000 & 1 & .999 & .002 \\
\cline { 2 - 8 } & Size_Bank & .000 & .000 & .000 & 1 & .997 & 1.000 \\
\cline { 2 - 8 } & Crisis & -.986 & 15874.115 & .000 & 1 & 1.000 & .460 \\
\cline { 2 - 8 } & Constant & 466.024 & 123457.438 & .000 & 1 & .989 & 3586.257 \\
\hline
\end{tabular}

a. Variable(s) entered in step 1: Crisis.

The probability of the Wald statistic for the variable "Crisis" is $1>$ 0.05. The null hypothesis that the $b$ coefficient for Crisis is equal to zero was not rejected. This means that the crisis coefficient is not significantly different from 0 . This supports the relationship that in both cases, "in time of crisis" or "in normal times", the strategy is not affected for heterogeneous boards. A heterogeneous board does not change the strategy in times of crisis. The crisis does not push these boards to choose defensive strategies. The results confirm both hypotheses H2a and H2b. 


\section{Discussion}

Our study is the result of several fundamental questions. Would the level of homogeneity between boards' members in terms of functional origin have an impact on strategies adopted by banks in the Lebanese banking sector? If one understands the influence of functional origins, what do we gain in terms of knowledge? Will crises in the banking industry have an effect on the relationship that lies between the functional origins of the management teams and the strategic choice?

We find that it is the degree of homogeneity in terms of functional origin between boards' members that influences the strategic choice. The education plays a major role in this relationship and its influence is significant. We noticed that if the experience is tested alone, it will also have a significant role. But the effect of the experience loses its meaning when tested along with the education.

The results obtained are encouraging. Testing hypotheses confirm some of our assumptions. Concerning the significance of the results, it seems that the academic education is the main factor that will affect the chosen strategy in times of crisis, which is logical in times of uncertainties.

Our tests show that it is the composition of the boards (in terms of educations) that will have a significant influence on the strategy. This applies in times of crisis as well as in normal times. Thus, when most members of the board have similar academic backgrounds, the strategy in times of crisis tends to be defensive, while in normal times the chosen strategies are offensive. While when most members of the board have different academic background, the crisis tends to have no effect on the strategy and the majority of boards choose offensive strategy at all times.

We found that, in similarity to the studies of Zorn (2004), Carpenter et al. (2001), Certo et al. (2006), the functional background of members will affect the strategy.

In his study, first we tried to test the link between the functional background of boards and strategies, taking into account the effect of crisis. Our sample was limited to 16 banks over a period of 10 years, which gave us one hundred and sixty observations to test.

The tests show that it is the boards' composition in terms of academic background that will affect the strategic choices. To improve the explanatory power of our models, three additional control variables were used:

- $\quad$ The average age of boards;

- $\quad$ The size of banks;

- $\quad$ The size of boards.

Interesting results emerge from our tests, and we have learned four lessons. The first is that as in previous research, we found that when measured alone, the experience will affect the strategic choices. The second 
is that the effect of the experience loses its meaning if it tested along with education, which could be explained by the uncertainty surrounding the crisis, in addition in our sample the average experience of boards are very close between banks, between 22 and 24 years on average. The third lesson, even if we had not been able to test it empirically, is that the entrenchment exists. For the period spanning over ten years and for the sixteen banks tested, there were only four changes in the management teams: two changes upon the death of two members and the other two changes occurred when two members were elected as deputies.

\section{Limitations}

Our study has several limitations. A total of 52 commercial banks operate in Lebanon, our initial sample size is considered small. Only 32 banks were appropriate candidates for data collection over a period of 10 years as we excluded the Lebanese banks with Arab control, the Arab and Foreign banks. Our sample, the 16 banks represents $34.6 \%$ of the total banks population, and $50 \%$ of the eligible banks. We were limited to 16 banks because, for unknown reasons, the other banks refused to provide copies of the missing annual reports and these reports were not posted online! The strategy was coded from the speech of the CEO, even if a second coding was done, it implies that the answers are not scientific and do not rely on numbers, but on perceptions. Because of the existing fraud in the Lebanese market, some companies produce erroneous annual reports intended to evade taxes, this may be the case in banks. Unfortunately, the existing political intervention in all sectors and industries in Lebanon can reduce the effect of Boards members on the strategic choice. In our sample and during the coding, we found two types of strategies: offensive and defensive strategies of diversification. The average board members' experience is similar in all banks, which could be the reason that prevented us from finding a significant relationship. There were only four changes in board members, we found that these changes are caused mainly by two factors: the death of a member, or his election as depute or minister and according to the Lebanese law, when elected they do not have the right to work in a private company. We noticed that some these members resumed their former jobs at the end of their mandate.

\section{Conclusion}

In conclusion, similar to previous studies, we found a link between the characteristics of boards and the strategic choice whether normal times or in times of crisis. A surprising result in our study is that we have not found a link between age, experience of boards and the strategic choice. Noting that, our study is one of the rare studies that investigate the effect of the 
characteristics of boards on the strategic choice, while taking into consideration the impact of crises.

By comparing our results to previous studies, our empirical tests show that the functional origin will affect the strategic choice (Zimmerman, 2008; Bunderson, 2003; Carpenter, 2002; Carpenter and Fredrickson, 2001; Bantel and Jackson, 1989; Govindarajan, 1989; Hambrick and Mason, 1984). However, unlike other studies (Alexiev et al, 2010; Certo et al., 2006; Cho and Hambrick, 2006; Beal and Yasai-Ardekani, 2000; Rajagopalan and Datta, 1996; Bantel and Jackson, 1989), the experience of boards in the banking industry when tested alone will have an effect, but if we test it along with the education it loses its significance. The crises variable has largely led to contradict previous studies mainly because of the uncertainty that exists during the times of crisis.

Previous studies that used the size of banks, the size of boards and the age of boards have found contradictory results (Kor and Misangyi, 2008; Goll et al., 2008; Naranjo-Gil and Hartmann, 2007; Kor, 2006; Carpenter, 2002; Richard and Shelor, 2002). In our study, we found no effect for these three variables on the strategic choices. Our study could be used as basis for future research in one way or another:

An empirical study using a larger number of variables. The number of variables in the literature is quite important. Moreover, empirical studies using other factors or combinations of factors rather than those we used are recommended (compensation, entrenchment ...)

1. In-depth case studies of more in-depth qualitative studies of Lebanese commercial banks are another important angle for future research.

2. Repeat the same study but using a larger sample;

3. Empirical or qualitative studies using the same factors in the banking industry in other countries.

4. Finally, empirical and qualitative studies using the same factors, but in a different industry.

\section{References :}

Albouy, M. (2013). La plus belle théorie financière ne peut donner que ce qu'elle a. Revue française de gestion, 228(9), 107-126.

Alexiev, A. S., Jansen, J. J., Van den Bosch, F. A., \& Volberda, H. W. (2010). Top management team advice seeking and exploratory innovation: the moderating role of TMT heterogeneity. Journal of Management Studies, 47(7), 1343-1364.

Angora, A., \& Tarazi, A. (2011). Crises bancaires dans les pays de l'UEMOA: Un système d'alerte avancée fondé sur une approche logit multinomiale. Brussels Economic Review, 54(1), 21-50. 
Arun, T. G., \& Turner, J. D. (2004). Corporate governance of banks in developing economies: concepts and issues. Corporate Governance: An International Review, 12(3), 371-377.

Association of Banks in Lebanon (2016). Lebanese Banking Sector. Available at http://www.abl.org.lb/landingpage.aspx?pageid=315

Auh, S., \& Menguc, B. (2005). Top management team diversity and innovativeness: The moderating role of inter-functional coordination. Industrial Marketing Management, 34(3), 249-261.

Awino, Z. B., Muchemi, A. W., \& Ogutu, M. (2011). Diversity in the top management teams and effects on corporate performance. Business Administration and Management, 1(3), 82-92.

Awino, Z. B. (2013). Diversity Management Strategies and Quality Decisions in the Banking Sector. American Journal of Business and Management, 2(2), 125-129.

Awino, Z. B. (2013). An Empirical Study of Top Management Team Diversity, And Performance in the Service Industry. Research Journal in Organizational Psychology and Educational Studies, 2(1), 25.

Bantel, K. A., \& Jackson, S. E. (1989). Top management and innovations in banking: does the composition of the top team make a difference?. Strategic Management Journal, 10(S1), 107-124.

Basle Committee on Banking Supervision, (1997). International convergence of capital measurement and capital standards. Basle Committee on Banking Supervision.

Basle Committee on Banking Supervision (2004). International convergence of capital measurement and capital standards: a revised framework. Basle Committee on Banking Supervision.

Baysinger, B., \& Hoskisson, R. E. (1990). The composition of boards of directors and strategic control: Effects on corporate strategy. Academy of Management Review, 15(1), 72-87.

Baysinger, B. D., Kosnik, R. D., \& Turk, T. A. (1991). Effects of board and ownership structure on corporate R\&D strategy. Academy of Management Journal, 34(1), 205-214.

Beal, R. M., \& Yasai-Ardekani, M. (2000). Performance implications of aligning CEO functional experiences with competitive strategies. Journal of Management, 26(4), 733-762.

Boeker, W. (1997). Strategic change: The influence of managerial characteristics and organizational growth. Academy of Management Journal, 40(1), 152-170.

Boone, C., \& Hendriks, W. (2009). Top management team diversity and firm performance: Moderators of functional-background and locus-of-control diversity. Management Science, 55(2), 165-180. 
Boyer, R., Dehove, M., \& Plihon, D. (2004). Les crises financières. La Documentation Française.

Bunderson, J. S. (2003). Team member functional background and involvement in management teams: Direct effects and the moderating role of power centralization. Academy of Management journal, 46(4), 458-474.

Buyl, T., Boone, C., Hendriks, W., \& Matthyssens, P. (2011). Top management team functional diversity and firm performance: The moderating role of CEO characteristics. Journal of management studies, 48(1), 151-177.

Cannella, A. A., Park, J. H., \& Lee, H. U. (2008). Top management team functional background diversity and firm performance: Examining the roles of team member colocation and environmental uncertainty. Academy of Management Journal, 51(4), 768-784.

Cao, Q., Simsek, Z., \& Zhang, H. (2010). Modelling the joint impact of the CEO and the TMT on organizational ambidexterity. Journal of Management Studies, 47(7), 1272-1296.

Carminatti-Marchand, G., \& Paquerot, M. (2003). The elite and their boards of directors. Corporate Ownership \& Control, 1(1), 112-128.

Carpenter, M. A. (2002). The implications of strategy and social context for the relationship between top management team heterogeneity and firm performance. Strategic Management Journal, 23(3), 275-284.

Carpenter, M. A., \& Fredrickson, J. W. (2001). Top management teams, global strategic posture, and the moderating role of uncertainty. Academy of Management Journal, 44(3), 533-545.

Carpenter, M. A., Sanders, W. G., \& Gregersen, H. B. (2001). Bundling human capital with organizational context: The impact of international assignment experience on multinational firm performance and CEO pay.Academy of Management Journal, 44(3), 493-511.

Carpenter, M. A., \& Westphal, J. D. (2001). The strategic context of external network ties: Examining the impact of director appointments on board involvement in strategic decision making. Academy of Management Journal, 44(4), 639-660.

Carson, C. M., Mosley, D. C., \& Boyar, S. L. (2004). Performance gains through diverse top management teams. Team Performance Management, 10(5/6), 121-126.

Certo, S. T., Lester, R. H., Dalton, C. M., \& Dalton, D. R. (2006). Top Management Teams, Strategy and Financial Performance: A Meta-Analytic Examination. Journal of Management Studies, 43(4), 813-839.

Chahine, S., \& Safieddine, A. (2008). Corporate governance and the external monitoring of banks in Lebanon. Corporate Governance, 8(3), 258-270.

Chevet, J. M. (1993). Les crises démographiques en France à la fin du xviie et au xviiie siècle: un essai de mesure. Histoire \& Mesure, 8(1), 117-144. 
Cho, T. S., \& Hambrick, D. C. (2006). Attention as the mediator between top management team characteristics and strategic change: The case of airline deregulation. Organization Science, 17(4), 453-469.

Coll R.B., \& Tucci L.A. (2001). Top Management Team composition, corporate ideology and organization performance. Mat Turter, 41(2): 109129.

Corm, G. (2005). L'économie libanaise: risques et perspectives. Accomex, 63(Méditerranée).

Creane, S., Goyal, R., Mobarak, A.M. and Sab, R. (2004). Financial sector development in the Middle East and North Africa. IMF working paper WP/04/201, IMF, Washington, DC, available at: www.imf.org/external/pubs/ft/wp/2004/wp04201.pdf

Cronbach, L. J. (1971). Test validation. Educational measurement, 2, 443507.

Daellenbach, U. S., McCarthy, A. M., \& Schoenecker, T. S. (1999). Commitment to innovation: The impact of top management team characteristics. R\&D Management, 29(3), 199-208.

De Vauplane, H. (2012). La gouvernance des banques à l'issue de la crise du système financier. Working paper.

Desjardins, J. (2005). L'analyse de régression logistique. Tutorial in quantitative methods for psychology, 1(1), 35-41.

Dezső, C.L. and Ross, D.G. (2012). Are banks happy when managers go long? The information content of managers' vested option holdings for loan pricing. Journal of Financial Economics, 106(2), pp.395-410.

Diemer, A. (2010). La planification concurrentielle, théorie et applications. Diemer A., Lallement J.

Dollinger, M.J. (1984). Environmental boundary spanning and information processing effects on organizational performance. Academy of Management Journal, 27(2), pp.351-368.

Dundas, K. N., \& Richardson, P. R. (1982). Implementing the unrelated product strategy. Strategic Management Journal, 3(4), 287-301.

Eisenhardt, K. M., \& Schoonhoven, C. B. (1990). Organizational growth: Linking founding team, strategy, environment, and growth among US semiconductor ventures, 1978-1988. Administrative Science Quarterly, 504529.

Finkelstein, S., \& Hambrick, D. C. (1990). Top-management-team tenure and organizational outcomes: The moderating role of managerial discretion. Administrative Science Quarterly, 484-503.

Finkelstein, S. \& Hambrick, D.C. (1996). Strategic Leadership: Top Executives and their Effects on Organisations. St. Paul, MN: West Publishing. 
Finkelstein, S., \& Hambrick, D. C. (1997). Review: Strategic Leadership: Top Executives and Their Effects on Organizations. Australian Journal of Management.

Finkelstein, S., Hambrick, D. C., \& Cannella, A. A. (1996). Strategic leadership. St. Paul, Minn.: West.

Finkelstein, S., Hambrick, D., \& Cannella, A. A. (2009). Strategic leadership: Theory and research on executives, top management teams, and boards. Oxford University Press.

Fligstein, N. (1993). The transformation of corporate control. Harvard University Press.

Fligstein, N. (2001). Social skill and the theory of fields. Sociological theory, 19(2), 105-125.

Goll, I., Brown Johnson, N., \& Rasheed, A. A. (2008). Top management team demographic characteristics, business strategy, and firm performance in the US airline industry: The role of managerial discretion. Management Decision, 46(2), 201-222.

Goll, I., Brown Johnson, N. \& Rasheed, A. A. (2007). Knowledge capability, strategic change, and firm performance: the moderating role of the environment. Management Decision, 45(2), 161-179.

Goll, I., Sambharya, R. B., \& Tucci, L. A. (2001). Top management team composition, corporate ideology, and firm performance. MIR: Management International Review, 109-129.

Govindarajan, V. (1989). Implementing competitive strategies at the business unit level: Implications of matching managers to strategies. Strategic Management Journal, 10(3), 251-269.

Güner, A. B., Malmendier, U., \& Tate, G. (2006). The impact of boards with financial expertise on corporate policies. National Bureau of Economic Research.

Gupta, A. K. (1984). Contingency linkages between strategy and general manager characteristics: A conceptual examination. Academy of Management Review, 9(3), 399-412.

Hambrick, D. C. (2007). Upper echelons theory: An update. Academy of Management Review, 32(2), 334-343.

Hambrick, D. C., Black, S., \& Fredrickson, J. W. (1992). Executive leadership of the high technology firm: What is special about it? Advances in Global High-Technology Mmanagement, 2, 3-18.

Hambrick, D. C., Cho, T. S., \& Chen, M. J. (1996). The influence of top management team heterogeneity on firms' competitive moves. Administrative Science Quarterly, 659-684.

Hambrick, D. C., Finkelstein, S., \& Mooney, A. C. (2005). Executive job demands: New insights for explaining strategic decisions and leader behaviors. Academy of management review, 30(3), 472-491. 
Hambrick, D. C., Geletkanycz, M. A., \& Fredrickson, J. W. (1993). Top executive commitment to the status quo: Some tests of its determinants. Strategic Management Journal, 14(6), 401-418.

Hambrick, D. C., \& Mason, P. A. (1984). Upper echelons: The organization as a reflection of its top managers. Academy of Management Review, 9(2), 193-206.

Hambrick, D. C., Nadler, D. A., \& Tushman, M. L. (1999). Navigating Change: How the CEOs, Top Teams and Boards Steer Transformation. International Journal of Physical Distribution \& Logistics Management, 29(4), 224-239.

Hastie, T., \& Tibshirani, R. (1986). Generalized additive models. Statistical science, 297-310.

Haunschild, P. R., \& Miner, A. S. (1997). Modes of inter-organizational imitation: The effects of outcome salience and uncertainty. Administrative Science Quarterly, 472-500.

Hendry, K., \& Kiel, G. C. (2004). The role of the board in firm strategy: integrating agency and organisational control perspectives. Corporate Governance: An International Review, 12(4), 500-520.

Hendry, K. P., Kiel, G. C., \& Nicholson, G. (2010). How boards strategise: A strategy as practice view. Long Range Planning, 43(1), 33-56.

Hermalin, B. E., \& Weisbach, M. S. (1991). The effects of board composition and direct incentives on firm performance. Financial Management, 101-112.

Hermalin, B. E., \& Weisbach, M. S. (2001). Boards of directors as an endogenously determined institution: A survey of the economic literature (No. w8161). National Bureau of Economic Research.

Herrmann, P., \& Datta, D. K. (2005). Relationships between Top Management Team Characteristics and International Diversification: an Empirical Investigation. British Journal of Management, 16(1), 69-78.

Hillman, A. J., \& Dalziel, T. (2003). Boards of directors and firm performance: Integrating agency and resource dependence perspectives. Academy of Management Review, 28(3), 383-396.

Hilb, M. (2005). New corporate governance: from good guidelines to great practice. Corporate Governance: an International Review, 13(5), 569-581.

Hoskisson, R. E., Hitt, M. A., Wan, W. P., \& Yiu, D. (1999). Theory and research in strategic management: Swings of a pendulum. Journal of Management, 25(3), 417-456.

Hoskisson, R. E., Eden, L., Lau, C. M., \& Wright, M. (2000). Strategy in emerging economies. Academy of Management Journal, 43(3), 249-267.

Hosmer Jr, D. W., \& Lemeshow, S. (2004). Applied logistic regression. John Wiley \& Sons. 
International Monetary Fund (IMF), (2009). Resilient Lebanon Defies Odds In Face of Global Crisis. Washington. Available at http://www.imf.org/external/pubs/ft/survey/so/2009/car081109a.htm James, W.L. and Hatten, K.J., 1995. Further evidence on the validity of the self-typing paragraph approach: Miles and Snow strategic archetypes in banking. Strategic management journal, 16(2), pp.161-168.

Jensen, M. C., \& Meckling, W. H. (1976). Theory of the firm: Managerial behavior, agency costs and ownership structure. Journal of Financial Economics, 3(4), 305-360.

Jensen, M., \& Zajac, E. J. (2004). Corporate elites and corporate strategy: How demographic preferences and structural position shape the scope of the firm. Strategic Management Journal, 25(6), 507-524.

Kor, Y. Y. (2006). Direct and interaction effects of top management team and board compositions on R\&D investment strategy. Strategic Management Journal, 27(11), 1081-1099.

Kor, Y. Y., \& Misangyi, V. F. (2008). Outside directors' industry-specific experience and firms' liability of newness. Strategic Management Journal, 29(12), 1345-1355.

Lado, A. A., Boyd, N. G., \& Wright, P. (1992). A competency-based model of sustainable competitive advantage: Toward a conceptual integration.Journal of Management, 18(1), 77-91.

Lopez, F. (2010). Too big to fail: gouvernance et régulation des banques. Revue d'économie financière, 187-199.

Mannix, E. and Neale, M.A., 2005. What differences make a difference? The promise and reality of diverse teams in organizations. Psychological science in the public interest, 6(2), pp.31-55.

Marimuthu, M., \& Kolandaisamy, I. (2009). Can demographic diversity in top management team contribute for greater financial performance? An empirical discussion. The Journal of International Social Research, 2(8), 273-286.

Marimuthu, M., \& Kolandaisamy, I. (2009). Ethnic and gender diversity in boards of directors and their relevance to financial performance of Malaysian companies. Journal of Sustainable Development, 2(3), p139.

Menguc, B., \& Auh, S. (2005). A test of strategic orientation formation versus strategic orientation implementation: the influence of TMT functional diversity and inter-functional coordination. Journal of Marketing Theory and Practice, 4-19.

Michel, J. G., \& Hambrick, D. C. (1992). Diversification posture and top management team characteristics. Academy of Management Journal, 35(1), 9-37. 
Miles, R.E., Snow, C.C., Meyer, A.D. and Coleman, H.J. (1978). Organizational strategy, structure, and process. Academy of management review, 3(3), pp.546-562.

Milliken, F. J., \& Martins, L. L. (1996). Searching for common threads: Understanding the multiple effects of diversity in organizational groups. Academy of Management Review, 21(2), 402-433.

Naranjo-Gil, D., \& Hartmann, F. (2007). Management accounting systems, top management team heterogeneity and strategic change. Accounting, Organizations and Society, 32(7), 735-756.

O’Reilly, C., Snyder, R., \& Boothe, J. (1993). Effects of executive team demography on organizational change. Organizational Change and Redesign, 147-175.

O'Regan, N. and Ghobadian, A. (2006). Perceptions of generic strategies of small and medium sized engineering and electronics manufacturers in the UK: The applicability of the Miles and Snow typology. Journal of Manufacturing Technology Management, 17(5), pp.603-620.

Palepu, K. (1985). Diversification strategy, profit performance and the entropy measure. Strategic Management Journal, 6(3), 239-255.

Plambeck, N., \& Weber, K. (2010). When the glass is half full and half empty: CEOs' ambivalent interpretations of strategic issues. Strategic Management Journal, 31(7), 689-710.

Polizatto, V. P. (1990). Prudential Regulation and Banking Supervision: Building an institutional framework for banks (Vol. 340). World Bank Publications.

Porter, M. F. (1980). An algorithm for suffix stripping. Program: Electronic Library and Information Systems, 14(3), 130-137.

Porter, M. E. (1986). Competition in global industries. Harvard Business Press.

Porter, M. E. (1987). From competitive advantage to corporate strategy. Harvard Business Review, 65(3), 43-59.

Porter, M.E. (1992). Capital disadvantage: America's failing capital investment system. Harvard Business Review, Vol. 70 No. 5, pp. 65-82.

Porter, M. E. (1996). What is strategy?. Harvard Business Review, 74(6), 6178.

Rajagopalan, N., \& Datta, D. K. (1996). CEO characteristics: does industry matter?. Academy of Management Journal, 39(1), 197-215.

Rajan, R. G., \& Zingales, L. (1998). Power in a Theory of the Firm. The Quarterly Journal of Economics, 113(2), 387-432.

Richard, O. C., \& Shelor, R. M. (2002). Linking top management team age heterogeneity to firm performance: Juxtaposing two mid-range theories. International Journal of Human Resource Management, 13(6), 958-974. 
Saidi, N. (2004). Corporate governance in the MENA region: improving transparency and disclosure. Paper presented at 2nd Middle East and North Africa Regional Corporate Governance Forum, Beirut.

Salem, R. \& Hamza N. (2003). L’évolution et la révolution de la théorie financière par rapport aux savoirs. XVIIème Congrès Annuel, XIIIème Congrès Franco-Espagnol, AEDEM Bordeaux.

Sanders, W. G., \& Carpenter, M. A. (1998). Internationalization and firm governance: The roles of CEO compensation, top team composition, and board structure. Academy of Management Journal, 41(2), 158-178.

Scialom, L. (2013). Économie bancaire. La Découverte.

Chahine, S. and Safieddine, A. (2008). Corporate governance and the external monitoring of banks in Lebanon. Corporate Governance: The international journal of business in society, 8(3), pp.258-270.

Simmonds, P. G., Dawley, D. D., Ritchie, W. J., \& Anthony, W. P. (2001). An exploratory examination of the knowledge transfer of strategic management concepts from the academic environment to practicing managers. Journal of Managerial Issues, 360-375.

Simon, H. A. (1948). Administrative Behavior: A Study of Decision-making Processes in Administrative Organization. With a Foreword by Chester I. Barnard. MacMillan.

Central Bank of Lebanon: http://www.bdl.gov.lb/

Song, J. H. (1982). Diversification strategies and the experience of top executives of large firms. Strategic Management Journal, 3(4), 377-380.

Stiglitz, J. E., \& Uy, M. (1996). Financial markets, public policy, and the East Asian miracle. The World Bank Research Observer, 11(2), 249-276.

The World Bank (2011). Basel III roadmap: lebanon's experience. Available at

http://siteresources.worldbank.org/FINANCIALSECTOR/Resources/DR_A

WAD_Implementation_of_Basel_III_The_case_of_Lebanon.pdf

Tihanyi, L., Ellstrand, A. E., Daily, C. M., \& Dalton, D. R. (2000). Composition of the top management team and firm international diversification. Journal of Management, 26(6), 1157-1177.

Van Knippenberg, D., De Dreu, C.K. and Homan, A.C., 2004. Work group diversity and group performance: an integrative model and research agenda.Journal of applied psychology, 89(6), p.1008.

VanHoose, D. (2007). Theories of bank behavior under capital regulation.Journal of Banking \& Finance, 31(12), 3680-3697.

Westphal, J. D., \& Zajac, E. J. (1995). Who shall govern? CEO/board power, demographic similarity, and new director selection. Administrative Science Quarterly, 60-83. 
Westphal, J. D., \& Fredrickson, J. W. (2001). Who directs strategic change? Director experience, the selection of new CEOs, and change in corporate strategy. Strategic Management Journal, 22(12), 1113-1137.

Wheatley, K., \& Doty, H. (2010). Executive compensation as a moderator of the innovation-performance relationship. Journal of Business and Management, 16(1), 89-102.

Wiersema, M. F., \& Bantel, K. A. (1992). Top management team demography and corporate strategic change. Academy of Management journal, 35(1), 91-121.

Zimmerman, M. A. (2008). The influence of top management team heterogeneity on the capital raised through an initial public offering. Entrepreneurship Theory and Practice, 32(3), 391-414.

Zorn, D. M. (2004). Here a chief, there a chief: the rise of the CFO in the American firm. American Sociological Review, 69(3), 345-364.

Zorn, D., \& Dobbin, F. (2003). Too Many Chiefs?. In How Financial Markets Reshaped the American Firm. Paper prepared for Constance Conference on Social Studies of Finance: Inside Financial Markets. University of Constance.

Zorn, D., Dobbin, F., Dierkes, J., \& Kwok, M. S. (2005). Managing investors: How financial markets reshaped the American firm. The Sociology of Financial Markets, 269-289.

Zreika, M., \& Elkanj, N. (2011). Banking efficiency in Lebanon: an empirical investigation. Journal of Social Sciences, 7(2), 199. 